\title{
Stereotip dan Konflik Antar Suporter Sepakbola Persibat dan Persip Pekalongan
}

\author{
Erik Bagus Prastyawan dan Fajar Junaedi*) \\ Program Studi Ilmu Komunikasi Universitas Muhammadiyah Yogyakarta \\ Jalan Brawijaya Kasihan Tamantirto Bantul Yogyakarta, Indonesia \\ koresponden: fajarjun@umy.ac.id
}

\begin{abstract}
ABSTRAK
Suporter sepakbola merupakan sebuah nyawa bagi klub sepakbola dan bahkan menjadi sebuah identitas dari kota itu sendiri. Rivalitas antarsuporter sepakbola terjadi di berbagai kota di Indonesia, salah satunya di wilayah pantai utara Jawa Tengah, yang melibatkan konflik dan berujung bentrok antara suporter sepakbola Persibat Batang dan suporter sepakbola Persip Pekalongan yang terjadi puncaknya pada tanggal 29 April 2017 saat kedua tim tersebut dipertemukan di kasta dan grup yang sama di liga 2 Indonesia. Sampai sekarangpun masih terjadi gesekan diantara keduanya. Penelitian ini berusaha mengkaji dari sudut pandang sebuah fenomena konflik diantara keduanya yang menimbulkan stereotip dan sebuah identitas suatu kelompok yang ikut berperan di dalamnya yang bertujuan untuk mencari dan mendeskripsikan faktor-faktor awal mula rivalitas diantara kedua suporter tersebut. Peneliti menggunakan metode pendekatan kualitatif dan data penelitiannya adalah data deskriptif dengan strategi studi kasus agar dapat menangkap fenomenafenomena yang ada di lapangan, sedangkan analisis datanya menggunakan analisis interaktif. Penelitian ini menemukan bahwa sebuah konflik suporter akibat adanya rivalitas dan fanatisme yang berlebihan, kemudian stereotip muncul dan terbentuk karena adanya perbedaan kelompok di antara keduanya yang saling bertikai, sedangkan identitas di dalam kelompok tersebut tidak lagi di pandang, siapa yang dianggap berbeda dengan kelompoknya itu adalah musuhnya. Akhirnya, identitas yang terbentuk di antara mereka bersifat relasional.

Kata Kunci : Suporter, Identitas, Konflik dan Stereotip
\end{abstract}

\begin{abstract}
Football supporters or fans are spirit for football clubs and even become an identity of the city itself. The rivalry of an Indonesian football club supporters are the social phenomenon. In a north coast region of Middle Java Province, recently there is a conflict and clashes between Persibat Batang football supporters and Persip Pekalongan football supporters. The conflict between football supporters from both clubs culminated on April 27, 2017 when the two teams were met in the level and the same group in second league Indonesia. Till now, there is still friction between both of them. So here the researcher then examines from the point of view of a phenomenon of conflict between the two that creates stereotypes and an identity of a group in it which aims to find and describe the factors of the beginning of the rivalry between the two supporters. Researchers used a qualitative approach method and the research data was descriptive data with a case study strategy in order to capture the phenomena in the field, while the data analysis used interactive analysis. This study found that a supporter conflict due to rivalry and excessive fanaticism, then stereotypes emerged and formed because of differences in groups between the two who fight each other, while the identity in the group is no longer viewed, who is considered different from the group is his enemy. Finally, the identity between football supporters are relational.
\end{abstract}

Keywords : Supporters, Identity, Conflict and Stereotype 


\section{Pendahuluan}

Perilaku konflik merupakan berbagai bentuk perilaku yang diciptakan oleh seseorang atau kelompok untuk membantu mencapai apa yang menjadi tujuan atau mengeskpresikan permusuhan pada musuh atau para pesaing mereka (Susan, 2009: 49). Konflik dilatar belakangi oleh perbedaan ciri-ciri yang dibawa dalam individu dalam suatu interaksi. Perbedaan tersebut menyangkut ciri fisik, kepandaian, pengetahuan, adat istiadat, keyakinan, dan sebagainya (Rusdiana, 2015: 68). Konflik bisa terjadi kapan saja dimana saja maupun antar individu, individu dengan kelompok, atau kelompok antar kelompok. Konflik tidak hanya terjadi di dunia politik saja, entah konflik antar agama, suku, ras, etnis dan sebagainya, konflik pun juga merahmbah di dunia olahraga yaitu salah satunya adalah olahraga sepakbola. Sepakbola mempunyai ciri khas yang sangat menonjol, yakni dengan adanya komunitas suporter atau pendukung dari kesebelasan yang manakalah sangat begitu fanatik dan ekpresif juga militan dalam mendukung tim kesayangannya, bahkan tidak dipungkiripun terkadang sampai menyebabkan timbulnya konflik fisik atau kekerasan verbal antar kedua kubu suporter entah diluar stadion maupun didalam stadion saat pertandingan sedang berlangsung.

Seperti konflik suporter sepakbola yang kerapkali terjadi di Indonesia belakangan ini. Kerusuhan suporter di Indonesia terjadi pada nyaris semua level kompetisi, mulai dari Liga Super Indonesia (ISL), divisi utama, divisi satu, divisi dua bahkan sampai ke pertandingan sepakbola antar kampung (tarkam). Yang lebih ironis, kerusuhan antar suporter telah menyebabkan nyawa melayang sebagai akibat bentrok fisik yang terjadi diantara suporter yang berkonflik (Junaedi, 2014: 107). Suporter merupakan salah satu faktor penting dalam sepakbola. Fungsi dan peranan suporter sebagai pemberi dukungan kepada klub. Kehadiran suporter dalam pertandingan dapat memberikan suntikan semangat maupun motivasi tersendiri bagi para pemain yang sedang bertanding. Suporter juga berfungsi untuk menjatuhkan mental para pemain lawan. Sepakbola tanpa suporter bagaikan sayur tanpa garam terasa hambar. Suporter dan sepakbola bisa dikatakan muncul beriringan. Dimana ada sepakbola disitu ada suporter (Chusnuddin, 2016: 101). Di Indonesia, suporter divonis memperburuk citra sepakbola dan dianggap menjadi problem bangsa. Tindak kekerasan, kerusuhan, dan jatuhnya korban baik luka, tewas, rusak, dan terganggunya ketertiban merupakan pranata sosial sampai prasarana umum merupakan citra buruk yang melekat pada suporter sepakbola Indonesia. Kerusuhan suporter yang terjadi di Indonesia sebenarnya bukan isu baru, karena sejak lama sudah sering terjadi (Suyatna dalam Junaedi, 2014: 107).

Konflik suporter Persibat Batang dan Persip Pekalongan, memang wilayah kabupaten dan kota yang bertetangga ini sebelumnya tidak memiliki sejarah rivalitas dalam persepakbolaan diantara keduannya. Kabupaten Batang dan Kota Pekalongan memang memiliki jarak wilayah yang dekat karena areanya yang bertetangga. Dari pusat kota maupun pusat pemerintahan dari masing-masing kedua wilayah tersebut hanya berjarak kurang lebih sepuluh kilometer dan hanya sekitar lima belas menit apabila ditempuh dengan berkendara menggunakan sepeda motor. Pertemuan keduanyapun disebut dengan laga derby karena dari kedua masing-masing klub tersebut memiliki makanan tradisional yang khas dan sama yaitu nasi Megono, maka laga pertemuan dari kedua tim yang berjuluk Laskar Alas Roban dan Laskar Kalong ini disebut dengan derby Megono. Istilah derby umumnya dipakai di dunia sepakbola untuk menyebut pertandingan antara dua klub yang berada di satu daerah atau satu kota. Pertandingan yang dilabeli derby selalu menyuguhkan aroma kompetitas yang tinggi karena dilakukan sebagai bentuk pembuktian yang paling jago atau yang paling hebat di daerah atau kota tersebut. Oleh karena itu, tidak jarang laga derby banyak menarik animo masyarakat untuk menjadi saksi mata pertandingan tersebut, khususnya masyarakat di kota bersangkutan (Marvin, 2014: 6).

Konflik antar suporter Persibat Batang dan Persip Pekalongan puncaknya terjadi di tanggal, 29 April 2017 ketika kedua klub bertetangga ini dipertemukan di kasta yang sama di liga 2 grup 3 Indonesia. Pertikaian yang terjadi antar dua suporter di Kabupaten Batang dan Kota Pekalongan ini memang semakin hangat untuk dibahas. Kondisi sarana dan prasarana serta keprofesionalan panitia pelaksana pertandingan sangat penting dalam sebuah pertandingan. 
Pertikaian yang terjadi di daerah-daerah konflik yaitu di Kota Pekalongan bagian barat dan juga di perbatasan antara Kabupaten Batang dan juga Kota Pekalongan yang rawan gesekan-gesekan ini semakin sering terjadi, tidak tahu itu berupa penghadangan ataupun pemukulan dan pengrusakan kendaraan dari masing-masing kedua suporter. Konflik suporter Persibat dan Persip ditanggapi serius oleh pemerintah Kabupaten dan Kota masing-masing klub berasal, serta juga tidak luput dari perhatian panitia penyelenggara (Panpel) petandingan dari keduanya.

Akibat terjadinya konflik dan pertikaian diantara kedua kubu suporter tersebut lalu muncul sentimen-sentimen antar kelompok yang menimbulkan stereotip diantara masing-masing keduanya hingga bagaimana mereka lalu saling beranggapan dan memandang. Dalam stereotip dan prasangka, proses yang terjadi dalam pikiran manusia adalah logika kategorisasi. Manusia menilai orang lain dengan melakukan kategorisasi pada orang lain, dimana kata sifat tertentu diidentikan dengan anggota kelompok yang menjadi bagian dari kategori tersebut (Junaedi, 2014: 79). Fenomena stereotip sendiri tidak lepas dari suatu kelompok, dan kelompok tersebut pasti memiliki sebuah identitas di dalamnya. Tajfel menjelaskan bahwa identitas sosial merupakan kesadaran individu bahwa dirinya merupakan anggota dari suatu kelompok tertentu, yang meliputi kesadaran akan perasaan-perasaan dan nilai-nilai yang penting bagi dirinya sebagai anggota dari kelompok tersebut (Tajfel dalam Susetyo, 2010: 61). Berdasarkan berbagai konflik yang sering terjadi dan pasti terdapat korban diantara kedua belah pihak seperti latar belakang yang telah diuraikan. Selain itu konflik seperti ini penting untuk diuraikan penyebabnya, karena seperti pendapat Ibn khaldun, bahwa konflik sebagai sesuatu yang tidak berdiri sendiri (Affandi, 2004: 73). Konflik juga memunculkan stereotip diantara kelompok yang saling bertikai dan pasti terdapat sebuah identititas yang ikut berperan dari sebuah kelompok tersebut di dalamnya.

Berdasarkan uraian di atas, maka perumusan masalah dalam penelitian ini adalah sebagai berikut: 1, Mengapa konflik dan stereotip antar suporter Persibat Batang dan Persip Pekalongan terjadi.

\section{Kerangka Teori}

Perasaan sangat memegang peranan penting dalam mempertajam perbedaan-perbedaan tersebut sedemikian rupa, sehingga masing-masing pihak berusaha untuk saling meghancurkan. Perasaan ini biasanya terwujud dalam perasaan amarah dan rasa benci yang menyebabkan dorongan untuk ingin melukai atau menyerang pihak lain, atau untuk menekan atau menghancurkan individu atau kelompok yang menjadi lawan. Pertentangan atau konflik adalah suatu proses dimana individu atau kelompok berusaha untuk memenuhi tujuannya dengan jalan menantang pihak lawan yang disertai dengan ancaman atau kekerasan (Soekanto, 1990: 119). Suatu konflik yang terjadi antar kelompok menjadi tidak sehat apabila masing-masing pihak di dalam mencari pemecahanya tidak lagi bersifat rasional tapi lebih bersifat emosional. Akibatnya yang terjadi adalah seperti tawuran, penjarahan, perusakan rumah warga, perkelahian antar kelompok di dalam masyarakat. Kekerasan sudah dijadikan sebagai media penyelesaian masalah.

Manusia sejak awal memiliki watak agresif sebagai akibat adanya animal power dalam dirinya yang mendorong untuk melakukan kekerasan serta penganiayaan. Agresifitas ini bisa berakibat terjadinya pertumpahan darah dan permusuhan. Agresifitas tersebut kemudian menjadi pemicu terjadinya konflik. Teori ini kemudian ditentang dengan teori yang menyebutkan bahwa agresifitas tersebut bukan hanya karena faktor animal power dalam diri manusia, tetapi juga karena frustasi, yakni ketika manusia tidak berhasil mendapatkan apa yang diinginkan. Menurut teori ini bukan karena instink manusia dalam melakukan kekerasan melainkan juga frustasi (Affandi, 2004: 85). Karena potensi inilah manusia juga dikenal sebagai rational animal. Potensi lain yang ada di dalam diri manusia adalah potensi akan cinta dengan kelompoknya (Khaldun dalam Munawwir, 1997: 236).

Dijelaskan bahwa munculnya stereotip terjadi karena ketidakmampuan manusia mempersepsikan/menangkap heterogenitas kelompok lain. Dalam konteks hubungan antar 
kelompok, stereotip memang memiliki peran penting (Susetyo, 2010: 42). Menurut Lippman dalam Warnaen (2002: 102) stereotip merupakan salah satu landasan faktual penting yang akan menentukan hubungan fungsional antar kelompok. Menurut Myers dalam Susetyo (2010: 73) antara stereotip dan prasangka seringkali dianggap memiliki pengertian yang sama. Namun Allport dalam Warnaen (2002: 104) menegaskan bahwa stereotip tidak identik dengan prasangka karena stereotip evaluasinya bisa positif. Allport juga menegaskan bahwa stereotip berubah sesuai dengan intensitas dan arah prasangka.

Perspektif identitas sosial sangat relavan dijadikan acuan penting dalam memahami fenomena stereotip dalam relasi antar kelompok (Susetyo, 2010: 61). Menurut Tajfel, Turner dan Gilles, secara teoritis identitas sosial merupakan serangkaian proses dan asumsi terintegrasi yang menjelaskan hubungan antara kekuatan sosiokultural dengan perilaku sosial individu. Selanjutnya Tajfel dalam Susetyo (2010: 61) menjelaskan bahwa identitas sosial merupakan kesadaran individu bahwa dirinya merupakan anggota dari suatu kelompok tertentu, yang meliputi kesadaran akan perasaan-perasaan dan nilai-nilai yang penting bagi dirinya sebagai anggota dari kelompok tersebut. Identitas sosial banyak mencakup karakteristik yang unik, seperti nama seseorang dan konsep diri. Hal ini juga berbeda dengan konsep diri, yakni gambaran diri tentang aspek fisiologis maupun psikologis yang berpengaruh pada perilaku individu dalam penyesuaian diri dengan orang-orang lain (Sherman dan Deauk dalam Baron 1993: 163).

\section{Metode}

Sebagai penelitian lapangan, bentuk penelitian ini menggunakan pendekatan kualitatif dan data penelitiannya adalah data deskriptif dengan strategi studi kasus agar dapat menangkap fenomena-fenomena yang ada di lapangan kemudian dikaji lebih mendalam lagi. David William (1995) menulis bahwa penelitian kualitatif adalah pengumpulan data pada suatu latar alamiah, dengan menggunakan metode alamiah dan dilakukan oleh peneliti yang tertarik secara alamiah (William dalam Moleong, 2012: 5). Desain dalam penelitian ini bersifat terbuka, disesuaikan dengan kondisi yang dijumpai di lapangan. Peneliti terjun langsung ke lapangan dan berinteraksi langsung dengan informan sampai mendapatkan informasi yang diinginkan dan lengkap. Semua informasi disesuaikan dengan fakta yang ada di lapangan, sehingga informasi yang didapat setiap saat dapat berubah sesuai dengan pengetahuan baru yang didapat.

Analisis data adalah proses penyederhanaan data kedalam bentuk yang lebih mudah dibaca dan diimplementasikan. Analisis data dilakukan dengan tujuan agar informansi yang dihimpun akan menjadi jelas dan eksplisit. Sesuai dengan tujuan penelitian maka teknik data yang dipakai untuk menganalisis data dalam penelitian ini adalah analysis interactive model sebagaimana diajukan oleh Miles dan Huberman yaitu terdiri dari empat hal utama yaitu (Miles dan Huberman, 1992: 15):

1. Pengumpulan Data

Data yang diperoleh dari hasil observasi, wawancara dan dokumentasi dicatat dalam catatan lapangan yang terdiri dua aspek, yaitu dsekripsi dan refleksi

2. Reduksi Data

Reduksi data merupakan proses seleksi, pemfokusan, penyederhanaan dan abstraksi. Cara mereduksi data adalah dengan melakukan seleksi, membuat ringkasan atau uraian singkat, menggolonggolongkan ke pola-pola dengan membuat transkip penelitian untuk mempertegas, memperpendek membuat fokus, membuat bagian yang tidak penting dan mengatur agar dapat ditarik kesimpulan.

3. Penyajian Data

Penyajian data yaitu sekumpulan informasi tersusun sehingga memberikan kemungkinan penarikan kesimpulan dan pengambilan tindakan. Agar sajian data tidak menyimpang dari pokok permasalan maka sajian data dapat diwujudkan dalam bentuk matrik, grafis, jaringan atau bagan sebagai wadah panduan informasi tentang apa yang terjadi. Data disajikan sesuai dengan apa yang diteliti. 


\section{Penarikan Kesimpulan}

Kesimpulan yang ditarik segera diverifikasi dengan cara melihat dan mempertanyakan kembali sambil melihat catatan lapangan agar memperoleh pemahaman yang lebih tepat. Selain itu juga dapat dilakukan dengan mendiskusikan. Hal tersebut dilakukan agar data yang diperoleh dan penafsiran terhadap data tersebut memiliki validitas sehingga kesimpulan yang ditarik menjadi kokoh (Miles dan Huberman, 1992: 15).

\section{Hasil dan Pembahasan}

Dalam penelitian ini, penulis berangkat dari sebuah konflik suporter sepakbola lokal dalam satu wilayah atau yang biasa disebut dengan laga derby. Konflik antara suporter sepakbola Persibat Batang dan suporter sepakbola Persip Pekalongan ini tidak hanya terjadi di dunia nyata saja, tetapi juga sudah merambah ke dunia maya. Konflik yang berujung bentrok di antara kedua suporter sepakbola tersebut, kemudian memunculkan sentimen-sentimen antar masing-masing kelompok yang menimbulkan sebuah fenomena stereotip diantara keduanya hingga mereka lalu saling beranggapan dan saling memandang satu sama lain. Kemudian dalam sebuah fenomena stereotip sendiri pasti terdapat sebuah kelompok dan identitas di dalamnya.

\section{A. Konflik Perdana Suporter Sepakbola Persibat dan Suporter Persip}

Fenomena konflik antara suporter sepakbola Persibat dan suporter sepakbola Persip merupakan fenomena yang terjadi antara dua kelompok sosial yang mempunyai kepentingan yang berbeda. Di satu pihak, sangat ingin tim kesayangannya menang, tapi dilain pihak kelompok lainnya juga menginginkan hal yang sama pula. Perbedaan kepentingan ini membuat konflik tersendiri bagi mereka. Pernyataan ini sejalan dengan pernyataan Simmel, tentang kelompok sosial: yang mengatakan bahwa sosiasi melihat pada proses interaksi sosial sebagai cara menciptakan kesatuan. Fenomena konflik jika dipandang sebagai proses sosiasi merupakan perubahan wujud dari sosiasi ke asosiasi, yaitu para individu yang berkumpul sebagai kesatuan masyarakat, yang didalamnya mempunyai sosiasi yang saling bermusuhan (Susan, 2010: 47).

Konflik antar suporter sepakbola Persibat Batang dan suporter sepakbola Persip Pekalongan ini puncaknya terjadi pada tanggal 29 April 2017 ketika kedua klub bertetangga ini dipertemukan di kasta yang sama di liga 2 grup 3 Indonesia. Berawal dari laga pertama yang digelar di markas kebanggaan warga Batang di Stadion Moh. Sarengat pada putaran pertama yang mempertemukan Persibat Batang dan Persip Pekalongan pada grup 3 liga 2 Indonesia musim 2017 yang berujung dengan kerusuhan dan bentrok antar suporter yang menelan beberapa korban luka baik materil maupun non materil. Bentrok dari kedua kelompok suporter tersebut terjadi di luar stadion pada saat mereka saling berpapasan ketika kedua kelompok tersebut sama-sama akan menuju stadion untuk menyaksikan jalannya pertandingan, faktor penyebabnya sepele karena saling ejek satu sama lain antar suporter dan saling terprovokasi dari pihak lain yang memang menginginkan kedua suporter tersebut berujung bentrok dan ricuh.

Kemudian di laga putaran kedua yang mempertemukan kembali antara Persip Pekalongan dan Persibat Batang yang diselengarakan di stadion Jendral Hoegeng Kota Pekalongan pada tanggal 29 Juli 2017 dan tanpa dihadiri oleh suporter sepakbola dari Persibat karena tidak dapat perijinan dari pihak kepolisian kota Pekalongan dan tanpa persetejuan oleh panitia penyelenggara Persip dikarenakan dengan alasan keamanan karena pada saat pertadingan putaran pertama di stadion Moh. Sarengat Kabupaten Batang kedua suporter tersebut berujung bentrok dan tidak kondusif. Bentrokpun kembali terjadi meski tidak dihadiri oleh suporter tamu di laga putaran kedua, seperti pada laga putaran pertama bentrok terjadi di luar stadion markas Persip Pekalongan seusai laga imbang berahir dengan skor kacamata. Kali ini yang menjadi sasaran adalah tim tamu dari Persibat Batang yang akan bertolak pulang ke Kabupaten Batang menggunakan bus yang sudah dikawal ketat oleh kepolisian dilempari oleh oknum dari kelompok suporter Persip Pekalongan di luar stadion Jendral Hoegeng Kota Pekalongan hingga jalan-jalan Pantura (Pantai 
Utara Jawa) Kota Pekalongan yang di penuhi kelompok suporter Persip, akibatnya kaca dari bis tim tamu Persibat pecah dan tim official serta pemain persibat mengalami luka-luka. Entah mungkin penyebabnya atas aksi balas dendam dari kejadian bentrok pertama di luar stadion Moh. Sarengat Kabupaten Batang saat suporter Persip Pekalongan bertandang ke markas Persibat Batang dan mengalami pelemparan dan penyerangan serta hadangan dari suporter tuan rumah Persibat Batang.

Pertikaian yang terjadi antar dua suporter di Kabupaten Batang dan Kota Pekalongan ini memang semakin hangat untuk dibahas. Kondisi sarana dan prasarana serta keprofesionalan panitia pelaksana pertandingan sangat penting dalam sebuah pertandingan. Pertikaian yang terjadi di daerah-daerah konflik yaitu di Kota Pekalongan bagian barat dan juga di perbatasan antara Kabupaten Batang dan juga Kota Pekalongan yang rawan gesekan-gesekan ini semakin sering terjadi, tidak tahu itu berupa penghadangan ataupun pemukulan dan pengrusakan kendaraan dari masing-masing kedua suporter. Konflik suporter Persibat dan suporter Persip ditanggapi serius oleh pemerintah kabupaten dan kota masing-masing klub berasal, serta juga tidak luput dari perhatian panitia penyelenggara (panpel) petandingan dari keduanya.

\section{B. Beberapa Faktor Penyebab Konflik Suporter Sepakbola Persibat dan Suporter Persip}

Berikut ini adalah beberapa hal yang melatarbelakangi konflik suporter sepakbola Persibat Batang dan Persip Pekalongan.

1. Sentimen Derby Megono

Terkait dengan tiga elemen suporter Persibat Batang yaitu Roban Mania, Brigata Ultras Roban, Roban Rewo Rewo dan juga dua elemen suporter Persip Pekalongan yaitu Kalong Mania dan Brigata Batik City, mereka adalah suporter sejati dari Persibat dan Persip yang berada dalam satu wilayah pantai utara Jawa Tengah. Kabupaten Batang dan Kota Pekalongan adalah wilaya tetangga, sebelah timur Kabupaten Batang adalah Kabupaten Kendal dan Kota Semarang, sedangkan sebelah barat Kota Pekalongan adalah Kabupaten Pemalang dan Kota Tegal. Kenyataan ini memberi peluang pertemuan kedua belah suporter. Jika Persibat sedang bertanding ke Tegal misal, pasti akan melewati Kabupaten Pekalongan, jika Persip bertandang ke Semarang misal, pasti akan melewati daerah Kabupaten Batang. Keadaan ini juga memicu terjadinya konflik antara suporter sepakbola Persibat dan suporter sepakbola Persip. Selain itu, pertandingan derby penuh dengan gengsi dan emosi, sedikit kesalahan saja dapat menyebabkan bentrokan besar, ditambah lagi dari kedua kesebelasan Persibat dan Persip berada dalam Liga dan grub yang sama Liga 2 Indonesia musim 2017.

Sebagai tim yang lebih senior, Persip Pekalongan pada saat itu secara prestasi kalah dengan Persibat Batang. Hal itu memunculkan gengsi dan kecemburuan sosial tersendiri bagi kedua kesebelasan. Bahwa perasaan memegang peranan penting dalam setiap unsur perbedaanperbedaan tersebut, sehingga masing-masing pihak dalam suatu lingkup rivalitas merasa mempunyai rasa kecemburuan sosial terhadap rivalnya dan berusaha untuk saling menjatuhkan. Faktor saling gengsi antara kabupaten dan kota, dimana kabupaten tidak mau kalah dengan kota, dan kota tidak mau dikalahkan dengan kabupaten, karena kota merasa mau lebih maju dan unggul dari kabupaten. Sedangkan kabupaten sendiri juga akan lebih merasa hebat kalo bisa menang dari kota. Makannya tidak heran kalau konflik atau gesekan akan terjadi diantara kubu suporter dari kedua belah pihak. Bentuk dari pada peranan perasaan itu terwujud dalam adanya gengsi antar suporter yang menyebabkan rivalitas tersendiri antara suporter sepakbola Persibat Batang dan suporter sepakbola Persip Pekalongan.

\section{Provokasi Media Sosial}

Konflik suporter Persibat dan suporter Persip juga tidak lepas dari adanya media sosial, segala bentuk provokasi muncul lewat media sosaial entah dalam bentuk audio visual, gambar, statement maupun bentuk yang lainnya. Hal ini sangat rawan bagi yang belum bijak dalam menggunakan media sosial terutama dalam mengakses suatu yang sifatnya umum dan sangat 
luas pasti sangat rawan sekali terpengaruh atau terprovokasi akan hal yang belum tentu benar kenyataannya. Hal itu terbukti bahwa dalam melihat sejarah dari suporter Persibat dan suporter Persip Pekalongan memang tidak ada rivalitas yang berlebihan diantara keduanya, hanya kebetulan saja rivalitas itu tumbuh setelah dalam persepakbolaan diwilayah pantai utara kususnya Persibat Batang dan Persip Pekalongan ini dipertemukan dikasta yang sama di Liga 2 Indonesia grub 3 musim 20017 jadi muncul suasana derby dan euforia baru di wilayah tersebut. Kurang bijaknya juga pengguna media sosial dalam mengakses susatu yang sifatnya umum jadi menimbulkan provokasi diantara suasana rivalitas tersebut. Provokasi tersebut memang nyata adanya dari oknum yang memang tidak bertanggung jawab yang secara sengaja memang menginginkan adanya bentrok dari kedua belah pihak tersebut.

\section{Stereotip dan Prasangka antarsuporter Persibat Batang dan suporter Persip Pekalongan}

Taylor dan Moghaddam dalam Susetyo (2010: 22), menjelaskan bahwa bahwa stereotip itu merupakan kesan kaku yang jauh dari kenyataan, keyakinan yang berlebi-lebihan, generalisasi berlebih-lebihan yang tidak akurat dan irasional. stereotip adalah sebuah kepercayaan atau persepsi seseorang berdasarkan kelompok. Jadi suatu informasi yang dimiliki seseorang atau kepercayaan tertentu dalam suatu informasi atau obyek yaitu yang dapat berupa dari orang, kelompok, isntitusi, perilaku, kebijakan atau peristiwa, atribut juga dapat berupa sifat, ciri, kualitas, atau hal-hal yang terdapat pada obyek. Dengan demikian stereotip dapat diartikan sebagai suatu informasi yang dimiliki dan diyakini suatu seseorang tentang ciri psikologis suatu anggota kelompok tertentu.

Sedangkan prasangka menurut Sarwono dalam Susetyo (2010: 72) bahwa prasangka timbul karena penilain yang tidak berdasarkan dan pengambilan sikap sebelum menilai dengan cermat, sehingga terjadi bias dari kenyataan yang sesungguhnya. contoh analogi prasangka jenis kelamin, kebanyakan tertuju dan mendiskriminasi kaum wanita. Di Arabsaudi wanita dilarang mengemudi, di Afganistan sejak kaum Taliban berkuasa wanita tidak boleh bekerja di kantor, tidak boleh keluar rumah tanpa ditemani suami, anak wanita tidak boleh sekolah. Di Indonesia prasangka dan diskriminasi terhadap wanita telah berlangsung sejak lama. Baru saja R.A. Kartini (1904) memperjuangkan emensipasi wanita, maka sedikit demi sedikit wanita memperoleh pendidikan dan mendapat posisi dan status yang semakin tinggi di dalam masyarakat. Akan tetapi masih sekarang pun masih terjadi diskriminasi terhadap wanita diberbagai bidang.

Stereotip suporter sepakbola Pekalongan terhadap suporter Persibat Batang adalah sekelompok anak muda dari Kabupaten Batang dan sekitarnya yang minim dengan sumber daya manusianya dan tingkat status pendidikan yang kurang karena dipandang dari sebuah lingkup kabupaten dan desa, sebuah wilayah kabupaten ternyata juga mempengaruhi status sosial dari masyarakatnya yang tinggal di wilayah kabupaten itu sendiri, sehingga stereotip suporter Pekalongan terhadap suporter Persibat terus terbangun dari hari ke hari karena warga kabupaten itu berbeda dengan warga Kota. Hal ini juga diperkuat dengan fenomena konflik yang terjadi antar suporter Persibat dan suporter Persip, dimana suporter perempuan dari Persip Pekalongan yang mengatas namakan Kalong Manis terluka akibat terkena lemparan batu oleh suporter sepakbola Persibat Batang.

Terbangunnya stereotip tentang suporter Persibat ini kemudian masuk dalam prasangka, fenomena ini pun akhirnya mendapat respon dari pihak kepolisian setempat dan panpel pertandingan dari pihak Persip Pekalongan, bahwa laga kedua yang akan diselengarakan di Kota Pekalongan tidak mengijinkan suporter Persibat untuk datang ke Pekalongan karena demi alasan keamanan dan untuk mengantisipasi terjadinya bentrok susulan. Karena bagi mereka suporter Persibat adalah suporter yang anarkis tidak pandang bulu dan kampungan.

Berbeda dengan suporter sepakbola Persip, stereotip suporter sepakbola Persibat yang melekat terhadap suporter sepakbola Persip Pekalongan adalah mereka suporter yang sombong, angkuh, suka meremehkan dan merendahkan, karean mereka merasa tinggal di wilayah kota dan jauh lebih maju dari wilayah kabupaten. Mereka juga merasa kelompok suporter mereka jauh 
lebih besar dan lebih berkembang dari suporter Persibat, hal tersebut juga diperkuat melalui fenomena konflik di media sosial, mereka selalu membanding-bandingkan wilayah kota dan kabupaten, warga kabupaten dianggap wilayah pelosok yang warganya minim dengan sumber daya manusianya juga dari tingkat pendidikan dan suka rusuh serta anarkis dan tidak berfikir panjang.

Berkaitan dengan suporter sepakbola Persibat Batang dan suporter sepakbola Persip Pekalongan, ankhirnya terlihat bahwa mereka saling memandang, mereka memiliki pandangan stereotip dan prasangka masing-masing antara keduannya. Dalam hal inilah identitas terbentuk secara relasional. Identitas yang bersifat relasional ini diakibatkan karena dilihat dari rivalitas kedua kelompok suporter tersebut. Namun fenomena yang menarik dari stereotip dan prasangka yang berkambang terhadap suporter keduanya adalah, bagaimana individu dari manusianya itu sendiri yang bisa menyikapinya, apa akan tetap mempunyai stereotip dan prasangka tersebut. Sebenarnya jika kita amati lebih jauh dan dalam, bahwa tidak semua suporter sepakbola Persibat itu kampungan dan minim sumber daya manusianya serta status tingkat pendikannya, namun ada juga suporter sepakbola Persibat yang mempunyai pikiran maju dan modern serta mempunyai tingkat pendidikan yang tinggi dan tidak kampungan. Sebaliknya juga dari suporter sepakbola Persip Pekalongan, tidak semua suporter Persip Pekalongan itu sombong, angkuh, suka meremhkan dan melecehkan serta paling merasa lebih besar dan maju. Ada juga suporter sepakbola Persip Pekalongan yang rendah hati, baik dan sopan santun. karena jika kita bicara stereotip dan prasangka di masyarakat maka yang ada hanya generalisasi terhadap suatu kelompok tertentu.

\section{Identitas Suporter Sepakbola Persibat Batang : Terpecah dalam Tiga Kelompok}

Persibat Batang mempunyai tiga elemen suporter yaitu, Roban Mania yang lahir di Batang tanggal 4 April 2004 yang beranggotakan 500 anggota, lalu ada Brigata Ultras Roban yang lahir di Batang tanggal 10 November 2012 yang beranggotakan 1.000 anggota, dan yang terahir adalah Roban Rewo Rewo yang lahir di Batang pada tanggal 7 April 2017 yang memiliki anggota terbanyak yaitu sekitar kurang lebih hampir 3.500 anggota. Ketiganya merupakan suporter resmi dari Persibat yang tersebar di berbagai wilayah Kabupaten Batang yang memiliki Identitas dan gaya yang berbeda-beda, namun ketiganya walaupun berbeda tetap menjadi satu kesatuan dan satu tujuan yaitu untu mendukung Persibat dan demi kejayaan Persibat Batang.

1. Roban Mania

Roban Mania merupakan suatu kelompok suporter yang bergaya Mania. Lambang Roban Mania adalah Banteng yang bermakna kuat dan kokoh dalam memegang prinsip, mencari jati diri dan menempatkan diri dibelantika suporter nasional. Roban Mania mempunyai julukan "Banteng Alas Roban" serta mempunyai selogan "Ramah dan Sopan Terhadap Tamu, Kreatif dan Anti Anarkis".

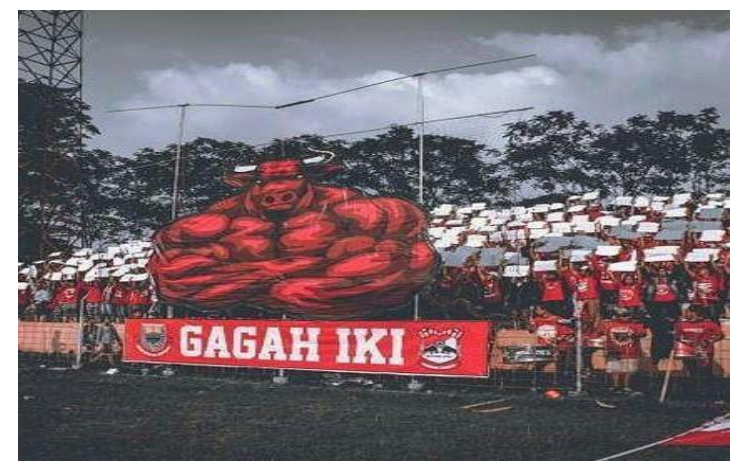

Gambar 1. Koreo 3D Banteng Suporter Roban Mania Persibat 
Bendera Roban Mania terdiri dari warna merah sebagai warna dominan, dan serta didominasi oleh warna hitam juga warna putih. Warna merah hitam disini mempunyai makna yang artinya berani dan tangguh serta pantang menyerah, sedangkan makna corak warna putih sendiri yang mempunyai makna ketulusan hati untuk kesejahteraan dan kebesaran Roban Mania. Roban Mania juga mempunyai mars yang biasanya dinyanyikan saat pertandingan berlangsung dan juga atribut yang diwujudkan dalam bentuk syal, jersey klub, read flare, bendera, trompet, smoke bom, topi bola, serta baju warna merah bergambar banteng sebagai warna identitas suporter Roban Mania dan warna klub dari Persibat Batang.

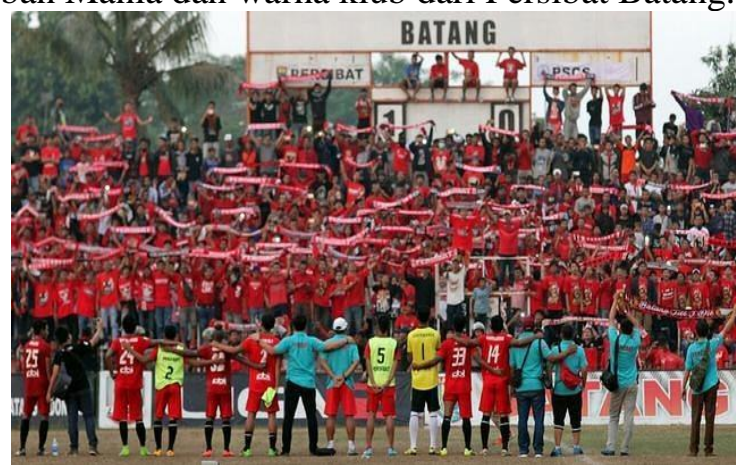

Gambar 2. Persibat Batang dan Atribut Roban Mania

\section{Brigata Ultras Roban}

Brigata Ultras Roban merupakan suatu kelompok suporter yang bergaya Ultras, dengan menirukan perilaku Ultras terutama Ultras Italia. Ultras merupakan representasi masyarakat Italia sekaligus identitas calcio. Seperti halnya kualitas Serie A yang menjadi kiblat dunia sepak bola juga strategi permainan ala catenaccio yang mengilhami banyak pelatih di dunia, maka Ultras kemudian menjadi rujukan dan refrensi bagi suporter di negara-negara lain kususnya di negara Indonesia sendiri.

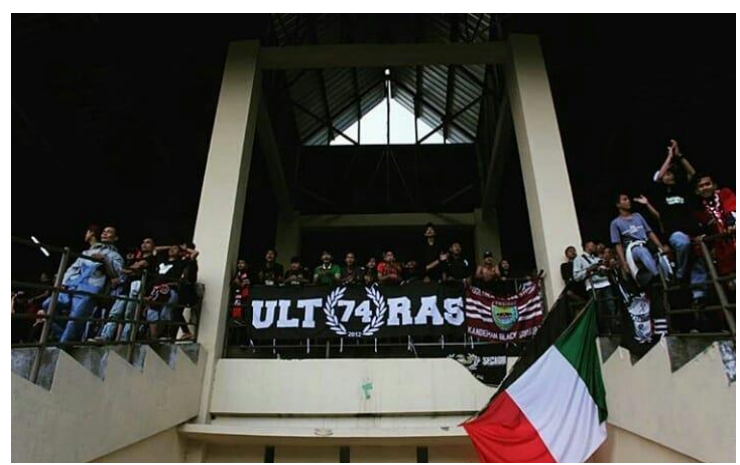

Gambar 3. Suporter Brigata Ultras Roban Persibat Batang saat Away ke Tegal

Brigata Ultras Roban dibentuk dan dibangun dengan inisiasi secara bersama-sama oleh kelompok mereka sendiri, mereka datang dan bergabung dikelompok bergaya Ultras ini sudah paham apa yang harus mereka lakukan. Intinya Brigata Ultras Roban ingin membentuk sebuah kelompok individu yang merdeka yang mempunyai ideologi. Suporter Ultras ini memang kebetulan dulu sebelum terbentuk adalah komunitas anak-anak fans club pecinta Liga Serie A, setelah paham dan mendalami idelogi tersebut makannya mereka lebih memilih bergaya Ultras. Brigata Ultras Roban mayoritas berpakaian warna hitam seperti Ultras-Ultras kebanyakan di Indonesia, mereka juga memujudkan dalam bentuk atribut seperti giant flag, syal, flare, smoke bomb pada seperti umumnya suporter Ultras di negara-negara lain. 


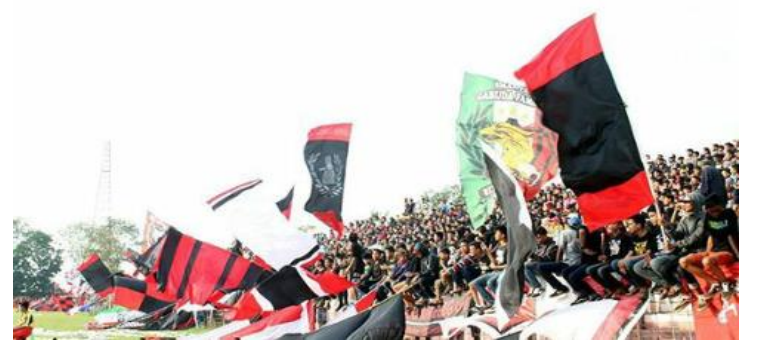

Gambar 4. Atribut Brigata Ultras Roban Persibat Batang

\section{Roban Rewo Rewo}

Roban Rewo-Rewo ditetapkan terbentuk tanggal 7 April 2017, meskipun nama Rewo Rewo sejak dulu sudah ada tapi Rewo Rewo yang dulu berbeda dengan Rewo Rewo yang sekarang, kalau Rewo Rewo yang dulu belum menggunakan salam satu Roban beda dengan yang sekarang. Sejak klub Persibat mulai bangkit dan naik kasta kembali Rewo Rewo pun seiringan muncul dan mulai menata diri, perkembangan Roban Rewo Rewo bisa dibilang membuat takjub masyarakat Batang karena anggota Roban Rewo Rewo terbentang dari penjuru pelosok wilayah Kabupaten Batang menurut dari data kordinasi wilayah yang ada, dan Roban Rewo Rewo sekarang menjadi basis kelompok suporter Persibat yang paling besar dan beranggotakan hampir tiga ribu lebih dan mengalahkan dua kelompok suporter yang bisa dibilang selalu eksis di Kabupaten Batang yaitu Roban Mania dan Brigata Ultras Roban.

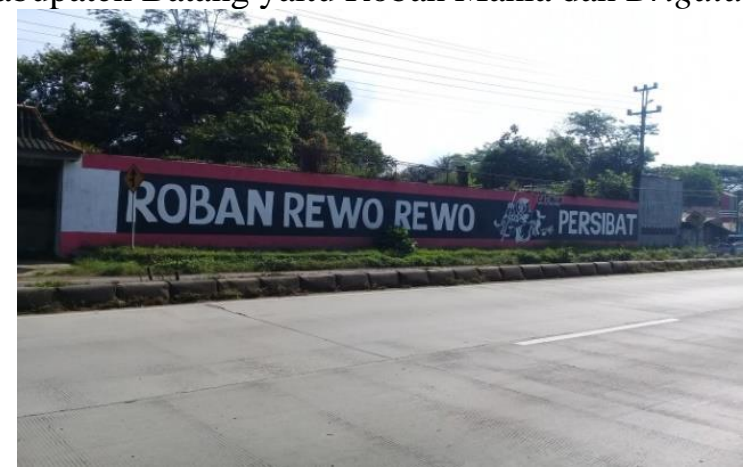

Gambar 5. Mural Roban Rewo Rewo

Identitas dari Roban Rewo Rewo sendiri bisa dibilang netral dan tidak mengacu gaya Mania, Ultras, Holigan, ataupun Casual. Roban Rewo Rewo lebih suka disebut dengan Persibat Fans, karena di dalam kelompok Roban Rewo Rewo sendiri memang berbagai macam elemen pun ada dan bercampur di dalamnya. Roban Rewo Rewo juga diwujudkan dengan atribut seperti suporter pada umunya seperti syal, jersey, kaos, flare, bendera, smoke bomb, bass drum dan senar drum. Mayoritas Roban Rewo Rewo memakai baju hitam, karena warna hitam itu adalah warna yang netral ujar dirigen Roban Rewo Rewo, warna hitam juga sudah dikenakan pada Rewo Rewo yang dulu sebelum menjadi Roban Rewo Rewo. 
Vol 1 No. 1, 2018, 1-14

DOI: https://doi.org/10.30596/persepsi.v1i1.2440

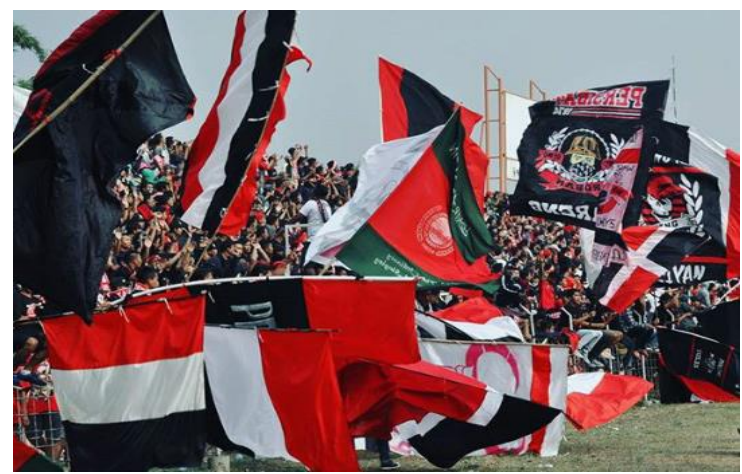

Gambar 6. Atribut Roban Rewo Rewo Persibat

\section{E. Identitas Suporter Sepakbola Persip Pekalongan : Antara Mania dan Ultras}

Persip Pekalongan juga memiliki dua elemen suporter diantaranya ada Kalong Mania dan Brigata Batik City. Kalong Mania lahir di Kota Pekalongan pada tanggal 11 Maret 2006 yang berbasis di Kota Pekalongan dan memiliki anggota sekitar 800-an anggota. Sedangkan Brigata Batik City sendiri juga lahir di Kota Pekalongan pada tanggal 16 Mei 2012 dan memiliki anggota kuranag lebih 1.000 anggota. Keduanya juga suporter resmi dari klub Persip Pekalongan yang memiliki identitas dan culture yang berbeda yang juga tersebar di seluruh wilayah Kota Pekalongan maupun hingga Kabupaten Pekalongan, walaupun berbeda namun tetap menjujung tinggi satu nama Persip dan demi kejayaan klub kebanggaan masyarakat Pekalongan yaitu Persip Pekalongan.

1. Kalong Mania

Kalong Mania merupakan identitas suatu kelompok suporter yang bergaya Mania yang berbasis dan bermarkas di Pekalongan Kota. Budaya Mania dan prinsip Mania memang sangat dipegang teguh oleh kelompok suporter Kalong Mania ini dengan alasan karena Mania itu asli suporter Indonesia yang harus dijaga dan dimasyarakatkan maupun serta dilestarikan keberadaannya.

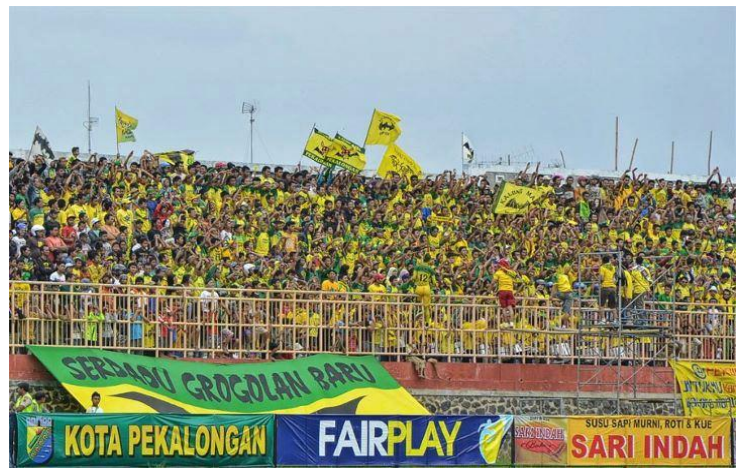

Gambar 7. Suporter Kalong Mania Persip Pekalongan

Lambang Kalong Mania sendiri adalah Kelelawar yang diambil dari sejarah Topo Kalong, Topo Kalong merupakan suatu tokoh sejarah yang membabat Kota Pekalongan yang pada jaman dulu Pekalongan masih lebat dengan kawasan hutan. Kalong Mania mempunyai julukan "Laskar Kalong" serta mempunyai selogan "Apapun Yang Terjadi Sampai Tuek Sampai Matek Ku Tetap Mendukung Persip Pekalongan", dalam bahasa Indonesia yang artinya "Apapun Yang Terjadi Sampai Tua Sampai Mati Aku Tepat Mendukung Persip Pekalongan". Bendera Kalong Mania terdiri dari warna kuning dan hijau, warna kuning disini mempunyai makna ceria, bahagia, energik dan penuh optimis untuk kejayaan Kalong Mania, serta warna 
hijau sendiri bermakna kedamaian. Kalong Mania juga mempunyai Mars tertentu dan koreo yang biasanya disajikan saat pertandingan berlangsung.

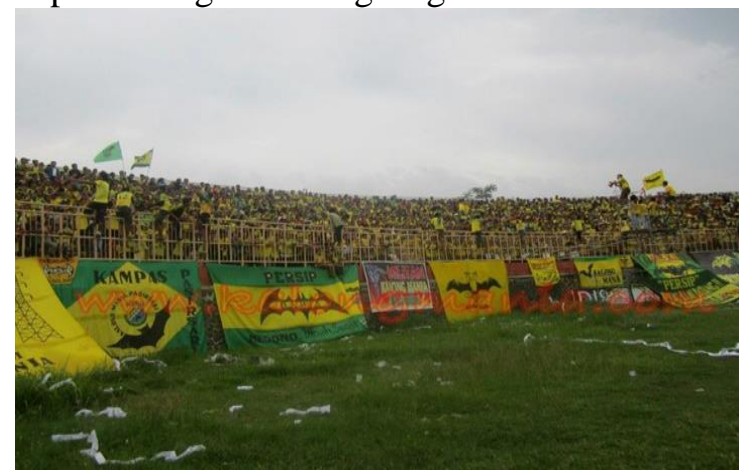

Gambar 8. Atribut Suporter Kalong Mania Persip Pekalongan

\section{Brigata Batik City}

Di Kota Pekalongan lahirlah kelompok suporter klub lokal Persip Pekalongan yang bergaya Ultras dengan nama Brigata Batik City. Kelahiran Brigata Batik City sendiri sangat besar pengaruhnya dari Ultras di negara asalnya yaitu Italia. Melalui siaran televisi Liga Italia Serie A yang banyak memperlihatkan gaya dukungan dan militansi ala Ultras di Italia sekarang sudah menyebar hingga ke Kota Pekalongan.

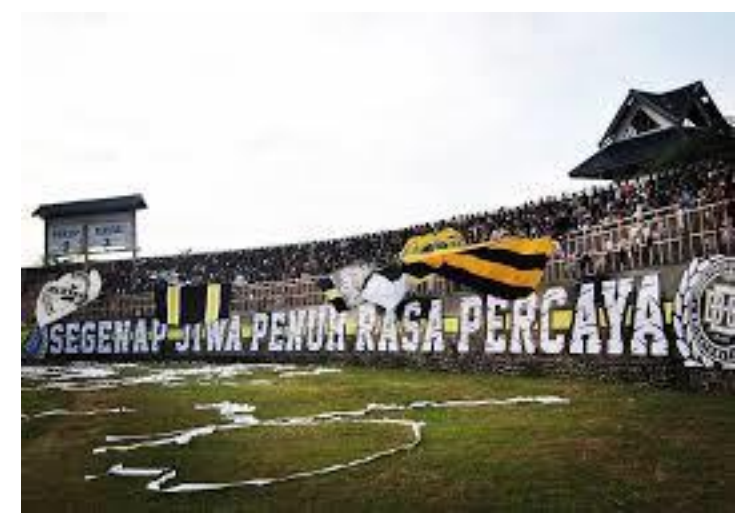

Gambar 9. Suporter Brigata Batik City Persip Pekalongan

Mereka memilih bergaya Ultras bukan berarti tanpa alasan tertentu. Ultras diambil dari bahasa latin yang berarti diluar dari kebiasaan. Para Ultras ini tak pernah berhenti menyanyi mendengungkan yel-yel tim favoritnya selama pertandingan berlangsung. Mereka juga rela berdiri sepanjang permainan dan menyalakan gas warna warni untuk mencari perhatian. Jika Anda sering melihat pergerakan manusia seperti gelombang di dalam stadion, itulah hasil instruksi dari para Ultras yang sangat kreatif kepada penonton yang lain. Karakter mereka temperamental seperti para Hooligan jika timnya kalah tanding atau diremehkan. Namun berbeda dengan Hooligan, tujuan utama mereka adalah mendukung tim, bukan untuk unjuk kekuatan lewat adu fisik. Anggota Ultras adalah mereka yang sangat setia dan loyal terhadap tim favoritnya cukup lama (Wahyudi, 2009: 102). 


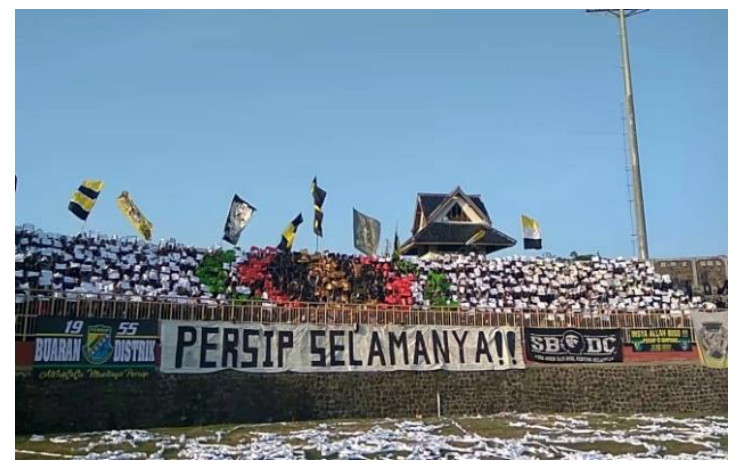

Gambar 10. Aksi Koreo Suporter Brigata Batik City Persip Saat di Tribun

\section{Kesimpulan}

Permasalahan dalam penelitian ini adalah tentang suatu kontroversi konflik yang terjadi antara dua kelompok suporter sepakbola Persibat Batang dan suporter sepakbola Persip Pekalongan. Demikian meskipun realitasnya suporter sepakbola sudah dianggap selalu membuat suasana hiruk pikuk kota menjadi tegang bagi masyarakat bila ada suatu pertandingan sepakbola dengan ulah konvoi entah prilaku negatif mereka, namun sepakbola juga merupakan sebuah hiburan masyarakat yang meriah dan merakyat sepanjang zaman bagi penggemarnya.

Melihat dari realita kedua tim dan suportrer masing-masing, kemudian timbul rivalitas tersendiri bagi keduanya. Konflik diantara keduanya ini bukan hanya terjadi di dunia nyata saja, tetapi juga terjadi di dunia maya. Saling ejek dan mengecam melalui media sosial juga menjadi pilihan dari beberapa suporter untuk mengintervensi suporter lawan. Kemudian vandalisme juga menjadi media mereka dalam berkonflik, terlihat dan terpampang ada tulisan-tulisan yang menggambarkan konflik antara suporter Persibat Batang dan Suporter Persip Pekalongan. Lagulagu dan atribut suporter juga menjadi media mereka.

Lalu kemudian terlihat dari stereotip dan prasangka yang muncul dari kedua kelompok suporter tersebut yaitu bagaimana keduanya saling memandang mempunyai stereotip dan prasangka tersendiri. Konflik yang terjadi antara suporter Persibat Batang dan suporter Persip Pekalongan juga merupakan konflik yang tidak terlepas dari suatu identitas kelompok yang ikut berperan di dalamnya. Dari kelompok kedua suporter tersebut di dalamnya memiliki identitas dan gaya yang berbeda walaupun satu visi misi dan tujuan. Seperti halnya kelompok suporter Persibat ada Ultras dan Manianya, bagitupun juga kelompok suporter Persip Pekalongan mempunyai Mania dan Ultras. Hal ini menunjukan bahwa terkadang bentrokan juga terjadi akibat fanatisme dan rivalitas yang berlebihan dan mengacu pada budaya dari Ultras itu sendiri yaitu bertarung tanpa terkait dengan adanya suatu pertandingan sepakbola atau di luar laga dengan istilah open fight (OF). Bertemu pada suatu tempat yang sudah di sepakati dengan dua kubu kelompok sama jumlah dan berkelahi tanpa menggunakan senjata melainkan dengan tangan kosong.

Berbeda dengan budaya Mania karena Mania adalah suporter asli Indonesia sedangkan Ultras suporter yang mengadopsi dari negara Italia. Bentrok juga terkadang seringkali terjadi di ruang publik yang menjadi daerah kekuasaan kota rivalitas yang dianggap sebagai daerah rawan untuk di lewati yang biasanya terjadi penghadangan atau adanya sweeping ketika suporter rival melewati kota atau daerah tersebut. Namun berbeda lagi jika sudah berbicara rivalitas dan fanatisme yang berlebihan terkadang sebuah identitas tidak lagi di pandang, siapa yang dianggap berbeda dengan kelompoknya itu adalah musuhnya. Dengan demikian, terlihat bahwa identitas suporter sepakbola di Batang dan Pekalongan adalah identitas yang bersifat relasional. 


\section{Daftar Pustaka}

Affandi, Hakimul i. (2004). Akar Konflik Sepanjangn Zaman, Elaborasi Pemikiran Ibn Khaldun. Yogyakarta: Pustaka Pelajar.

Baron, Byrne. (2005). Psikologis Sosial Jilid 2. Jakarta: Erlangga.

Chusnuddin, Ahmad Arif. (2016). Kota Sepak Bola Itu Bernama Surabaya: dalam Sirajudin Hasbi dan Ferry Triadi Sasono [ed] (2016), Sepakbola 2.0. Yogyakarta: Fandom

Junaedi, Fajar. (2014). Merayakan Sepak Bola Fans: Identitas dan Media. Yogyakarta: Buku Litera.

Marvin, Rockin. (2014). Derby 20 Rivalitas Terbaik Antar Klub Sepak Bola Dunia. Jakarta: Be Champion (Penebar Swadaya Grup).

Miles, B. Mathew dan Michael Huberman. (1992). Analisis Data Kualitatif Buku Sumber Tentang Metode-metode Baru. Jakarta: UIP.

Munawwir, Warson A. (1997). Kamus Al-Munawwir Arab-Indonesia. Yogyakarta: Pustaka Progresif.

Rusdiana, A. (2015). Manajemen Konflik. Bandung: Cv Pustaka Setia.

Susan, Novri. (2009). Pengantar Sosiologi Konflik. Edisi Revisi. Jakarta: Prenada Media Group.

Susetyo, Budi. D. P. (2010). Stereotip dan Relasi Antar Kelompok. Yogyakarta: Graha Ilmu.

Wahyudin, Hari. (2009). The Land Of Hooligans: Kisah Para Perusuh Sepak Bola. Yogyakarta: Garasi.

Warnaen, Suwarsih. (2002). Stereotip Etnis Dalam Masyarakat Multietnis. Yogyakarta: Penerbit Mata Bangsa. 